\title{
Three Communication Difficulties of EFL Students
}

\author{
Grettel Vargas Jiménez \\ Escuela de Lenguas Modernas \\ Universidad de Costa Rica \\ Sede Rodrigo Facio \\ Recinto de Paraíso \\ Sede del Atlántico
}

\begin{abstract}
In spite of the diversity of resources (media, Internet, software, videos, social networks, etc.) many students present a lot of difficulties in developing their communication skills in learning English as a foreign language (EFL). Indeed, there are three aspects that affect the students' oral production negatively. First, lack of motivation that could be manifested in anxiety and students' low self-esteem. Second, the learning environment which includes the teacher's methodology and classroom environment in which the absence of an EFL speaking social context does not provide a natural content to stimulate communication. Third, mother tongue interference that is in trying to develop EFL with non-native speakers learners where students (and teachers) tend to translate everything to the first language; as a result, this practice reduces the possibility of thinking in EFL due to the lack of meaningful situations and real life contexts developed in class. However, the purpose of this article goes beyond proving that these three aspects affect the communicative skills of EFL learners. In fact, its purpose is to provide valuable information about the causes of this problem for improving fluency among EFL learners.
\end{abstract}

Key words: motivation, learning environment, mother tongue, interference, English foreign language, communication

\section{Resumen}

A pesar de la diversidad de recursos (medios de comunicación, Internet, software, videos, redes sociales, etc.), muchos estudiantes presentan dificultades durante su proceso de aprendizaje de inglés como lengua extranjera. Ciertamente, existen tres aspectos que afectan negativamente la producción oral de los estudiantes. Primero, la falta de motivación que podría ser manifestada en ansiedad y baja autoestima. Segundo, el ambiente de aprendizaje que incluye la metodología del profesor y el ambiente de la clase en donde la ausencia de un contexto social de un segundo idioma no estimula la comunicación en situaciones de la vida real. Tercero, la interferencia de la lengua materna que se refleja en el 
hecho de que muchos estudiantes (incluso profesores) tienden a traducir y a utilizar la lengua materna en la clase de inglés como lengua extranjera; como resultado de esta práctica, se reduce la posibilidad de pensar y utilizar esa segunda lengua en diferentes contextos y situaciones significativas desarrolladas en clase. Sin embargo, el propósito de este artículo va mas allá de describir cómo estos tres aspectos afectan la producción oral de los alumnos de inglés como lengua extranjera en el aula. De hecho, el propósito es proveer información valiosa acerca de las causas de estos fenómenos para mejorar la fluidez en el uso del inglés como lengua extranjera entre los educandos.

Palabras claves: motivación, ambiente de aprendizaje, lengua materna, interferencia, inglés como lengua extranjera, comunicación

$\mathrm{S}$ tudents' oral production in English as a foreign Language (EFL) is one of the most challenging aspects that teachers and learners face in the process of acquiring the language. Basically, students of EFL face problems in developing fluency in speaking because of difficulties related to their motivation, low self-esteem, anxiety, first language interference, and the learning environment.

This is a field research which tries to prove why some students cannot speak EFL fluently, and how the above mentioned three aspects affect their oral performance. All the information on which this article is based comes from books authored by specialists in the field, and from Internet publications.

This research is divided into three chapters. The first one is about the role of motivation in EFL acquisition and how low self-esteem and anxiety affect the oral performance of EFL students. This chapter is based on the books The Relationship between SelfEsteem and the Oral Production of a L2, Creating Context for SL Acquisition by Arnulfo G. Ramírez, and finally
Rod Ellis with The Study of SL Acquisition. On the other hand, the second chapter refers to the learning environment discussed in the book Language Two by Heidi Dulay, Marina Burt, and Stephen Krashen. Dulay, Burt, and Krashen analyze how environmental factors influence the production of communication of a second language such as the classroom environment, constant grammar correction, and a poor EFL environment. The last chapter is about the role of first language (language interference) in the acquisition of EFL. This chapter is based on the book Language Two by Dulay, Burt, and Krashen, who explain how interference and transfer of the mother tongue affect oral production of a foreign language. Also, they give a very clear explanation about the premature use of second language and its phonological performance. Moreover, they analyze the interaction between two languages (English and Spanish). Likewise, Rod Ellis' book The Study of SL Acquisition is also cited because it explains the importance of different social factors and second language acquisition. 


\section{Methodology}

In order to gather information, this field research included the application of a participant observation instrument and a closed question interview involving 14 students of an advanced level at Centro Cultural Costarricense Norteamericano (CCCN). The sample was based on EFL acquisition in conversational courses and the prestige of the CCCN that is focused on the communicative approach as main criteria. The participant observation was done on September 10, 2007. Among the objectives that were taken into consideration for the developing of this instrument were:

- To observe the performance of students while they are speaking the target language (English). Then, to establish how the L1 affects (interferes) their EFL production.

- To perceive the behavioural patterns in which EFL learners are motivated to learn.

- To observe the role of the teacher in the classroom in order to establish how she/he can positively or negatively influence the learner's desire and willingness to learn.

- To diagnose the behavioural patterns of EFL students and how the environment affects them in a positive or negative way.

- To recognize the kind of methodologies the teacher applies in class.

- To identify in which situations students use their L1.

- To observe the way the teacher corrects his/her students.

- To categorize the learning routines in order to establish how they contribute to the learning environment.
Hence, a guideline of about 14 items was designed with the purpose of answering the following questions:

- Does constant grammar correction interfere with the oral production of L2 students?

- Is the L2 lesson focused on grammatical structures or communicative activities?

- Is the lesson focused on the teacher or the students?

- Does the teacher encourage students to participate in oral activities?

- Is it allowed to speak Spanish during the class?

- How is the relationship between the students: friendly, respectful, or aggressive?

- How is the relationship teacher/ students: friendly, respectful, or aggressive?

- Does the teacher correct his/her students in an appropriate way?

Regarding the closed question interview, its purpose was to obtain information about three communication difficulties that EFL students face during their learning process in class. The students responded a multiple choice questionnaire of 14 questions in English in order to analyse: the most difficult aspect in speaking English, students' most frequent mistake when speaking English, student relationship with classmates and teacher, techniques to improve English conversation, error correction, kind of activities developed in class, and teacher's techniques developed in the English lesson among others.

In relation to the informants of this research project, a number of 
14 students were selected at $\mathrm{CCCN}$ at Barrio Dent, San Pedro, Montes de Oca, San José. The learners' ages range between 17 to 24 years old. All of them come from downtown San José and surroundings (Moravia, Guadalupe, Coronado, San Pedro, Curridabat, Desamparados,etc). The younger students (between 17 and 18 years old) were still studying at high school, and the rest of them perform different kinds of jobs.

After collecting the data over a period of three months, it was processed, interpreted and added to the information obtained from the documentary sources examined, all of which contributed to test the thesis statement proposed for this article.

\section{Literature Review}

Everyday EFL students face problems in developing their communicative skills. Basically, their problems are related to fluency in speaking. In terms of fluency, there are three aspects that influence their oral performance in EFL acquisition: first, the student's level of motivation due to psychological factors such as low selfesteem and anxiety, L1 interference, and finally the influence of the learning environment.

This article will try to determine why some students, in spite of being able to read, and understand English well, cannot speak English fluently. In addition, it is intended to establish the relationship between these three aspects in the oral production of EFL learners.

Motivation moves a person towards certain attitudes and interests that keep him/her motivated to learn, pass an examination, get a better job, learn about other cultures and people, etc. Indeed, "motivation involves the attitudes and affective states that influence the degree of effort that learners make to learn a L2" (Ellis, 1997, p.75). In spite of that, this motivation can be influenced (especially in the classroom) by psychological factors such as low self-esteem and anxiety. "High self-esteem makes people more willing to speak up in groups and to criticize the group's approach. Leadership does not stem directly from self-esteem, but self-esteem may have indirect effects" (Baumeister, 2003, 2). But, if a person feels inferior to others it will affect his/ her oral (fluency) performance.

On the other hand, anxiety is another important aspect that affects fluency in speaking EFL. In this regard, "anxiety is defined as a state of apprehension; a vague fear that can have a negative effect on motivation and that can result in a poor performance, which produces more anxiety" (Ramírez, 1995, p.167). This is especially clear in EFL classrooms when students avoid participating in oral activities, in competitive environments, where they tend to compare themselves to others. In fact, their fear of making mistakes increases their anxiety about being humiliated by others. In summary, both aspects (low self-esteem and anxiety) affect directly the oral production of EFL students.

In like manner, EFL students face problems of language interference. For example, a native Spanish speaking student studying EFL tends to add an "e" in words such as: special, state, student, and study because the vowel e comes before [S] in many Spanish words: estado, estudiante, estudiar, 
etc. "This is also evident in Spanish speakers when learning English, who tend to eliminate the final $-\mathrm{s}$ of the third person singular" (Fanselow \& Crymes, 1976, p.130). Also, "interference is manifested in the language the learner learns, not the first language of the learner" (Dulay, Burt, \& Krashen, 1982, p.99). In addition, Fanselow and Crymes emphatize that "the special care required to avoid overlapping points of interference (e.g., the tendency to aspirate the final consonants in Puerto Rican Spanish as students of African American dialect" (p.13). Finally, language interference is one of the most difficult task that EFL learners face because of the absence of a 100\% L2 environment.

In summary, this research will try to explain, based on the writing of different authors mentioned in this review, how these three communication difficulties approached in this investigation interfere in their oral production. However, it is important to mention that every student is different and unique, and that it is not possible to generalize communication problems to all of them.

\section{Factors that Affect Motivation in Second Language Learning}

In the process of EFL acquisition, motivation has been one of the most important factors that contributes to successful learning. As Ellis (1997) mentions "motivation involves the arousal and maintenance of curiosity in which learners feel personally involved in learning activities" (p. 76). On the other hand, "without sufficient motivation, even individuals with the most remarkable abilities cannot accomplish long term goals, and that there is no appropriate curricula and teaching techniques that ensure student achievement" (Ying, 2005, n.p.). In addition, a demotivated student prefers to abstain from participating in "communicative activities, loosing interest, and becoming more frustrated in the process of learning a L2" (Ellis, 1999, p.81). For that reason, it is very important to provide a space during class for creating students confidence and facilitating their participation in order to keep them motivated to learn. In conclusion, "motivation can result both from learning and produce learning" (Ellis, 1997, p.76).

Additionally, Ellis (1997) suggests that "there are two kinds of motivation: instrumental and resultative" (p. 75). In instrumental motivation, learners feel that the process of learning EFL is important since they can improve their economic status and also their educational opportunities, while resultative motivation is derives from learning. That is, "learners who experience success in learning may become more or less motivated to learn" (Ellis, 1997, p. 76).

Evidence suggests that resultative motivation depends (or it is the effect) on learner's success and good results, then "it seems evident that a motivated student will learn better than one that is not" (Timothy, 2007, n.p.). This is especially clear in EFL classrooms where the role of motivation is related to the role of the teacher who can positively or negatively influence the learner's desire and willingness to learn. For example, "it may be possible that some grading policies and certain types of language activities can result 
in stressful situations as well as in motivational events" (Ramírez, 1995, p.167). For some EFL learners, especially children, motivation is the key to continue learning the target language. Finally, whatever the reasons for learning EFL are, the effects of motivation are essential in the acquisition of a foreign language since it affects learners in a positive or negative way.

\section{The Learning Environment's Influence}

The learning environment affects the oral performance of an EFL learner if continuously subjected to grammar correction. In particular, "several factors can limit the beneficial effects of natural exposure to a L2: a lack of peers who speak the target language natively, and incomprehensive communication" (Dulay, Burt \& Krashen, 1982, p.17). This is a great limitation since EFL learners do not have the opportunity to interact with native speakers so their learning process is focused (most of the time) on the grammatical rules and vocabulary of the target language (Dulay, Burt \& Krashen, 1982, p.20).

In spite of the fact that they are able to write, read, and understand English well, many EFL learners are not able to speak fluently. Instead of developing natural "communication (ideas, thoughts, opinions, feelings, beliefs, etc.), they are more aware of "sounding" grammatically correct using rules and structures, but not expressing themselves" (Dulay, Burt \& Krashen, 1982, p. 35). EFL acquisition happens within an environment in which many other agents who may or may not be supportive for EFL students intervene (teachers or classmates). It is clear that learning EFL is more than understanding rules and grammatical structures.

In order to establish a successful learning environment, it is essential to take into account the affective aspects of the classroom climate, "which include student's perceptions about learning, feelings generated by and about the teacher, and the learning routines which contribute positively or negatively to the learning environment" (Ramírez, 1995, p.361). Hence, it is necessary to determine how significant is the role of the teacher in class in terms of classroom's management, teaching methodologies and techniques implemented during classes, as well as error correction, willingness to teach, etc. In addition, Ramírez (1995) underlines that "a teacher-centered class that does not integrate the student's necessities provides a negative environment for learners since it follows a set curriculum, with no regard to the student's needs" (p.363).

\section{Language Interference}

The third aspect which affects EFL learners' fluency is the L1 influence or language interference. Similar to the learning environment, EFL students face the problem of learning a foreign language in a L1 context. Basically, "language interference or language switching occurs when two language communities are in contact" (Dulay, Burt, \& Krashen, 1982, p. 98). This is especially clear in the case of the Spanish native speakers learning EFL. As Ellis mentions (1994) "the structures of the L2 speech of Spanish learners of English provide unambiguous evidence of transfer: I not have a bike = yo no 
tengo una bicicleta, the dog it ate $=$ el perro se lo comió" (p. 343). Also, Spanish speakers tend to confuse Spanish grammar with English grammar when they speak. For example, "we know from the observation of many cases that the grammatical structure of the native language tends to be transferred" (Dulay, Burt, \& Krashen, 1982, p. 99). This is evident in Spanish speakers when learning English since "they tend to confuse subject verb agreement: people is (gente es), he look, they looks" (Fanselow \& Crymes, 1976, p.130).

\section{Results}

During the interviews, students at the CCCN were asked about why they are interested in learning English. In figure 1 , one can note that $14 \%$ of the total sample of 14 students interviewed, expressed that they studied the language for pleasure, while $29 \%$ of them said they studied English for work reasons. Another $43 \%$ of them expressed that they were studying English just for learning, and the last 14\% of the students said they were there for other reasons, which included answers like, "for improving their future," and "because they liked the language." Most of the students agreed that they are highly motivated for learning English because they like the language. The evidence suggests that students of CCCN really want to learn since they decided to study there.

On the other hand, since motivation is related to the EFL learner's performance, low-self esteem has a negative effect on the EFL learners' oral production. For example, "if a L2 learner feels that he/she is a worthless or bad learner, he/she feels that he/she cannot speak a L2 because he/she does not have the ability to do it"(Dulay, Burt \& Krashen, 1982, p.227). As a result of the low self-esteem, EFL learner acts according to his own perspective: he/ she is not able to participate, not able to speak, not able to understand, and not able to be satisfied with himself, avoiding interaction with others. The students' perception about their performance when speaking English is shown in figure 2.

Figure 1

Students Motivation for Learning English

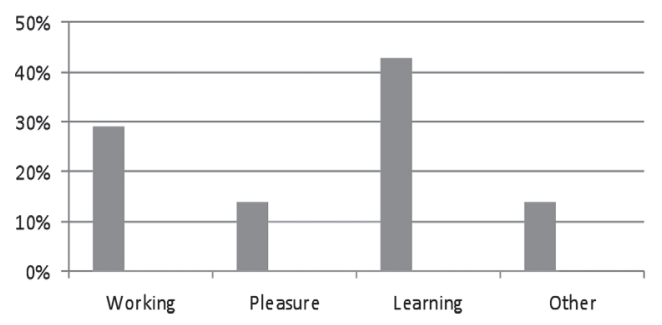

Source: Interview applied to students at CCCN on October 20, 2007.

Figure 2

Students Perception about their Performance when Speaking

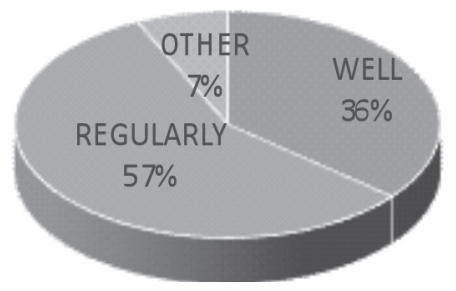

Source: Interview applied to students at CCCN on October 20, 2007 
In this figure, 5 of the 14 students (36\%) said their performance is good, 8 of them (57\%) said regular, and 1 of them $(7 \%)$ that he/she writes better than speak. In spite of the fact that they are in an advanced level, they consider that their oral performance in English is regular and they are not able to speak as well as they want.

Unfortunately, students with low self-esteem tend to receive low grades because they refuse to participate in oral or communicative activities. In fact, EFL learners are afraid of other's disapproval (classmates, teachers, friends, family, etc.). In fact, "this kind of students face problems with global (the individual evaluation of a person) and the specific self-esteem (evaluations resulting from certain life situations such as social interaction, education, etc.)" (Dulay, Burt \& Krashen, 1982, p.229). In addition, Ellis (1997) also supports this thesis when he cites a student's remark: "I keep thinking that others are better at language that I am..." (p.481).

Finally, the evidence suggests that low self-esteem affects the oral production of EFL students since their low self-concept impedes their participation in communicative activities (they feel inferior than others and are not able to speak).

Another psychological aspect that affects the oral production of EFL students is anxiety. Similar to low self-esteem, anxiety may result in avoidance behaviours: nervousness, not participating in class, and in some cases panic of speaking (Ramírez, 1995, p.167). For example, some EFL students experience anxiety when the teacher ask them questions in class or when speaking in front of people because their anxiety often results from feeling threatened in an environment in which they may be exposed to mockery or criticism. One example of this is the learner who is afraid of being ridiculed for a mistake: "I am obviously very afraid to make a mistake in front of the class- and I always feel very embarrassed about stammering" (Ramírez, 1995, p. 82). In addition, since the EFL learner knows that he is judged by his teachers and classmates, there is more tenseness and he/she becomes very much afraid to make mistakes.

Another aspect that also damages oral production in the EFL learners is competition. "Some students become anxious when they compare themselves with other learners in the class and find themselves less proficient" (Ellis, 1999, p. 480). A competitive learner who compares himself/herself to others may be victim of anxiety (Ellis, 1997, p.79). When the student feels less competent than others, his/her anxiety increases damaging his/her oral performance and fluency. There is enough evidence to show that anxiety is an important factor in the EFL acquisition, mainly in speaking. Unless, students feel more competent to speak, anxiety levels will affect their oral production in the foreign language.

An important aspect to take into account in order to create a positive class environment is that teachers should use appropriate techniques for giving students feedback, and for explaining new topics or grammatical items, or any other aspects that may be difficult to them. In response to the question: "What kind of activities does the teacher use to improve your conversational skills in English?", the students at CCCN provide the following answers shown in Table1. 
Table 1

Techniques used by the teacher in order to Improve English Conversation in class

\begin{tabular}{lcc}
\hline & Frequency & Percentage \\
\hline Role plays & 4 & $29 \%$ \\
Games & 3 & $21 \%$ \\
Speeches & 6 & $43 \%$ \\
Other: (1 listening- & 1 & $7 \%$ \\
1 speaking) & & 100 \\
Total & 14 & \\
\hline
\end{tabular}

Interview applied to students at CCCN on October 20, 2007

Regarding the techniques the teacher uses to improve English conversation in class, 4 of them (29\%) consider that they perform role plays very frequently in class, 3 of them (21\%) think that they perform games in class for improving their conversation skills, 6 of them (43\%) mention speeches, and 1 of them (7\%) other aspects such as listening and speaking.

On the other hand, some teachers are not concerned about developing the four language skills (listening, speaking, writing, and reading) in a L2 classroom. Instead of that, they focus on constant grammar correction, use of the students' native language during the class, and center the learning process on the textbook only. Moreover, "the lack of interaction, communication, and individual student contributions affects the learner oral performance" (Ramírez, 1995, p.361). For instance, some teachers prefer learning environments in which their students ought to be quiet and passive and are not permitted to move around. "Other teachers do not encourage students to work together to complete certain tasks, contributing to develop excessive competition and hostility among the stu- dents" (Ramírez, 1995, p.362). In brief, "the teacher's methodology focused on leading students to view the language only as an academic subject does not contribute to successful language communication" (Ramírez, 1995, p.363).

These examples show that formal language environments, in which the form (structure) is more important than the content of (natural) communication, do not encourage learners to participate in oral activities; therefore, it harms the student possibilities of learning EFL in a spontaneous way.

During the participant observation, that was done before interviewing the students, the students asked some questions in Spanish to the teacher although they were not allowed to speak Spanish in the EFL classrooms at CCCN. In fact, some of them used to ask questions to the teacher in Spanish mainly when they did not understand an unknown word or when they had any doubt related to the activities they should perform in class as well as grammatical explanations explained by the teacher. Similarly, the learners tended to speak Spanish with their classmates while they were working in groups. Nevertheless, they made the 
effort to speak English the majority of the time during the English class.

\section{Figure 3}

\section{Language used by Students during the English class}

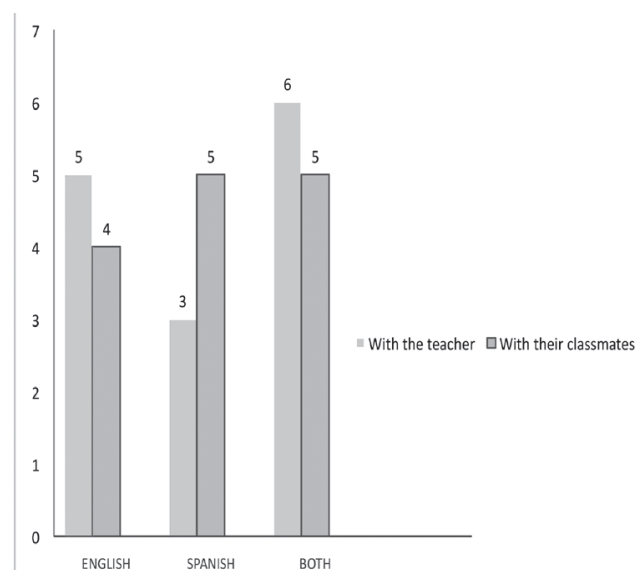

Source: Participant Observation to the students at CCCN on September 10, 2007

Table 2

Language Students' Use to Communicate in Class

\begin{tabular}{lcc}
\hline & Frequency & Percentage \\
\hline English & 8 & $57 \%$ \\
Spanish & 0 & $0 \%$ \\
Both & 6 & $43 \%$ \\
Total & 14 & $100 \%$ \\
\hline
\end{tabular}

Interview applied to students at $\mathrm{CCCN}$ on October 20, 2007

Similarly, during the interview performed on October 20, 2007, the learners expressed that they use Spanish and English at the same time during classes. This is clear in response to the question: "What language do you speak mostly in class?", because 8 of the 14 students (57\%) mention English, and 6 of them (43\%) consider they speak both (English and Spanish) in class. Even though some of them still have problems in using EFL in class, using both Spanish and English at the same time, most of them speak English in class.

Mainly, "the points of interference are based on phonological features" (Fanselow \& Crymes, 1976, p.130). One example of this is the pronunciation of the simple past tense of regular verbs that represents a problem for EFL learners. For instance, instead of saying worked [workt] they say [workid].

During the observation done on September 10, 2007, the students at CCCN worked individually or in groups. When the learners committed any mistake, the instructor corrected them in an opened class in order to clarify their mistakes without mentioning their names in a very respectful way, and by providing grammatical or phonological explanations. At the moment of the interview, the students at the CCCN supplied to the question: "What is a frequent mistake that you commit in speaking English?"

\section{Figure 4 \\ Students Most Frequent Mistakes when Speaking English}

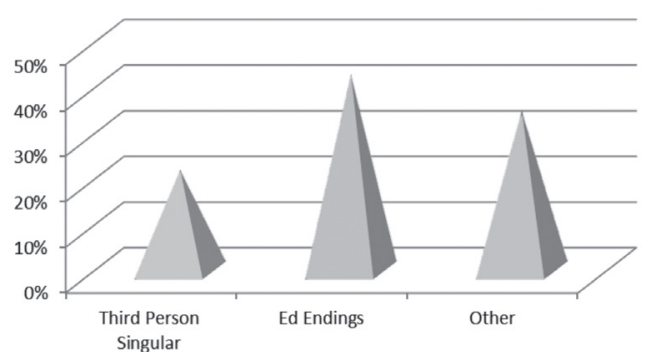

Source: Interview applied to students at CCCN on October 20, 2007 
Regarding students' most frequent mistakes when speaking, 3 of them (22\%) consider the production of third person singular rule in simple present tense the most difficult aspect in speaking English; 6 of them (43\%) think it is the pronunciation of the regular verbs in the simple past tense -ed endings, and 5 of them (35\%) consider other aspects difficult (3 grammar, 1 prepositions, 1 vocabulary). Nevertheless, they did not mention language interference as a frequent mistake which affects their oral production, but they recognize that they use both (Spanish and English) in class.

In addition, Dulay, Burt, and Krashen (1982) refer to linguistic borrowing as: "the attempt by a speaker to reproduce in one language, patterns learned in another" (p. 99). This is clear when false cognates are used, transferring their meaning in the L1 to English suceso $=$ success, actualmente $=$ actu ally, guachiman = watchman; embarrassed is not the same as embarazada, as realize, should not be confused with the Spanish word realizar.

These examples show that L1 interference does not help in the development of EFL students' oral production because the learner is always thinking of the L1 meanings and intentions. Also, the EFL student is confused by the different meanings of the target language.

\section{Conclusion}

The evidence suggests that there is a lot of aspects which affect the oral production of EFL students. However, this documentary research has been focused on three communicative problems that affect fluency of EFL learners such as the student motivation due to psychological factors such as low selfesteem and anxiety, language interference, and finally the influence of the learning environment. First of all, the effects of motivation are essential in the acquisition of EFL since they affect learners in a positive or negative way. In terms of self-confidence, the harmful influence of low self- esteem is evident in communicative activities in which affected students refuse to participate because they feel "inferior" than others, and they are not able to speak a foreign language. On the other hand, anxiety is the result of fears and insecurity, especially if the learner is afraid of being ridiculed for a mistake, or being judged by teachers and classmates.

Another aspect that interferes in fluency development is the learning environment. This is caused by methodologies focused on grammatical explanations in which the form (structure) is more important than the content (natural) communication when students try to express themselves in natural ways. Finally, since the absence of a 100\% English environment facilitates L1 interference, the learner is always trying to translate every word he/she learns into his/her mother tongue.

In conclusion, the analysis carried out in this article shows that in the acquisition of EFL, the development of fluency in speaking has been one of the most difficult tasks for students, since these three communication difficulties lead them to avoid speaking the foreign language being learned. Besides, it is very important to consider the learner needs, problems, abilities, and limitations in learning EFL, in order to resort to different activities for encouraging students to speak in a free 
and natural way. In the specific case of countries in which the official language is not English, as in the case of Costa Rica, many students, in spite of learning EFL in formal environments (high schools, institutes, schools, universities, etc.) during three or more years, they are not able to speak fluently. The problem also has to do with the fact that EFL curriculum emphasizes reading and grammar, reducing the possibilities of developing communicative skills for EFL learners.

However, the situation is different at Centro Cultural Costarricense Norteamericano (CCCN) since its curriculum is based on communication. Indeed, CCCN promotes the use of the Task Based Instruction (TBI) in which language is used as a vehicle for communication where students interact with each others in a very participative way. Nevertheless, this paper demonstrates that in spite of that, some of them still use Spanish in class, which is 6 of the 14 students (43\%) of the advanced group analyzed. Furthermore, 5 of the 14 students (36\%) said they developed their English oral performance well, but 8 of them (57\%) said they did it regularly and 1 of them (7\%) that he/she writes better than speak. The evidence suggests that their oral performance in English is regular, and they feel not able to use EFL accurately. Finally, in relation to the most difficult aspect in speaking EFL, 6 of the 14 students (43\%) believe that the production of the regular verbs in the simple past tense -ed endings is especially difficult for them, as well as 3 of them (22\%) consider harder the production of third person singular rule in simple present tense and 5 of them (35\%) con- sider other aspects difficult (3 grammar, 1 prepositions, 1 vocabulary).

In summary, in relation to the thesis statement of this field research, students of EFL of an advanced level at CCCN face problems in developing fluency in speaking because of problems related to first language interference, that has been proved regarding the use of both (English and Spanish for students). As a result, their oral performance perception is that they speak English regularly and not well. In addition, it is important to clarify the role of the teacher as a facilitator, who promotes the use of English in class, who has been willing to help her students by using the target language (English) in context without translation.

As a result of the analysis carried out in this article, it is important to recommend developing different activities in class in order to motivate students to participate and speak more actively. For example, for teenagers or young adults, it is recommended to discuss current topics related to their age and the kind of things they do as young people: dancing, practice sports, using technology, etc.; in order to talk about topics that they would like to share with other young people. Also, it is advisable to discuss different "polemic" topics in which they can feel free to express their opinions (in favor or against). In fact, it is possible in large classes to develop debates in two groups.

In addition, it is very important to take into account the students' needs during the learning process considering that every student is different and each one has different ways of learning. For that reason, it is essential to make an effort to develop the four different 
skills (listening, speaking, reading, and writing) in class, in order to keep students motivated to learn.

Finally, whatever the reasons for learning EFL are, for teachers to teach through oral activities must be viewed as an art; for students, it should be a pleasure. At the end the most important thing is to communicate with each other, interacting in a very comfortable learning environment: it may be difficult, but not impossible.

\section{Bibliography}

Baumeister, R.F. (2003). Physiological Science in the Public Interest. Washington, DC.

Dulay, H., Burt, M., and Krashen, S. (1982). Language Two. New York: Oxford UP.

Ellis, R. (1994). The Study of SL Acquistion. New York: Oxford UP.

Ellis, R. (1997). Second Language Acquisition. New York: Oxford UP.

Ellis, R. (1999). Learning a Second Language Through Interaction. Penn- sylvania: Library of the Congress Cataloging- in- Publication Data. Fanselow, J.F., and Crymes, R.H. (1976).On TESOL'76. Washington: Library of Congress Catalog Card.

Ramírez, A.G. (1995). Creating Context for Second Acquisition: Theory and Methods. New York: Longmon Publishers.

Scarcella, R., Andersen, E., and Krashen, S. (1990). Developing Communicative Competence in a Second Language. Boston: Heinle \& Heinle Publishers.

Seliger, H.W., and H. Long, M. (1983). Classroom Oriented Research in Second Language Acquisition. Boston: Newbury House Publishers, Inc.

Timothy, M. (2007). Critique of Krashen VI- the Affective Filter. Minnesota: UP, May 2007 <http:// www. creativecommons/interlanguage. may 07/.Mason.htm>

Ying, S. (2005). Motivation and Demotivation. New York: UP, July 2005. <http://www. dalianmaritimeuniversity/jul05/ Song.html> 
